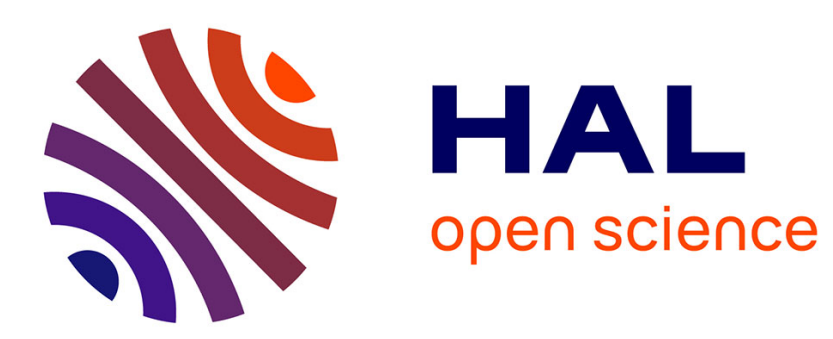

\title{
Atomic Layer Epitaxy in Deposition of Various Oxide and Nitride Thin Films
}

\author{
M. Leskelä, M. Ritala
}

\section{To cite this version:}

M. Leskelä, M. Ritala. Atomic Layer Epitaxy in Deposition of Various Oxide and Nitride Thin Films. Journal de Physique IV Proceedings, 1995, 05 (C5), pp.C5-937-C5-951. 10.1051/jphyscol:19955111 . jpa-00253780

\section{HAL Id: jpa-00253780 https://hal.science/jpa-00253780}

Submitted on 1 Jan 1995

HAL is a multi-disciplinary open access archive for the deposit and dissemination of scientific research documents, whether they are published or not. The documents may come from teaching and research institutions in France or abroad, or from public or private research centers.
L'archive ouverte pluridisciplinaire HAL, est destinée au dépôt et à la diffusion de documents scientifiques de niveau recherche, publiés ou non, émanant des établissements d'enseignement et de recherche français ou étrangers, des laboratoires publics ou privés. 


\title{
Atomic Layer Epitaxy in Deposition of Various Oxide and Nitride Thin Films
}

\author{
M. Leskelä and M. Ritala
}

Department of Chemistry, University of Helsinki, P.O. Box 6, FIN-00014 Helsinki, Finland

\begin{abstract}
Atomic Layer Epitaxy (ALE) is a chemical vapor phase thin film deposition method which is based on saturative surface reactions. As the film is growing in a self-limiting manner ALE is a promising method to deposit thin, high-quality films for micro- and optoelectronics. In the present paper the deposition of different dielectric oxides, conducting oxides as well as nitrides is reviewed giving emphasis to precursors and their effect on growth mechanisms and film properties.
\end{abstract}

\section{INTRODUCTION}

The development in microelectronics is connected to the development of thin film technologies. For example in silicon technology the ULSI chips need nanoscale components. This size reduction requires improving process control, lower processing temperatures to prevent diffusion, better definition and quality of interfacial regions $[1,2]$. This means that there is a permanent need for better thin film deposition processes and new materials.

In recent years there has been considerable activity on the deposition of metal oxide thin films on a variety of substrate materials. Oxides are known from their chemical inertness, good high temperature properties and resistance to oxidation. Characteristic for oxide thin films is their optical transparency, high electrical resistivity, low thermal conductivity, diamagnetism and chemical stability [3]. Exceptions exist, of course, and some oxides are conducting and even superconducting. Oxide thin films are interesting because of their many applications in microelectronic [4,5], optoelectronic [6-8] and superconducting $[9,10]$ devices. The function of the oxide films in these devices may be insulating, conducting, superconducting or they may be used as buffer or protecting layers.

Nitride films can be divided in two groups: transition metal nitrides and nitrides of the main group elements from which the most important are $\mathrm{Si}_{3} \mathrm{~N}_{4}, \mathrm{BN}, \mathrm{AlN}$ and $\mathrm{GaN}$. The nitride films of the main group elements are used as passivation and dielectric layers [11] and $\mathrm{GaN}$ as a wide band gap $(3.4 \mathrm{eV})$ semiconductor in optoelectronic devices [11,12]. The transition metal nitride films, especially TiN, are extensively used as wear resistant coatings on cutting tools and as diffusion barriers and nucleation layers in semiconductor devices [13,14]. Owing to the need of an improved conformality, the deposition of nitride films by chemical methods instead of a physical ones has gained growing attention.

Atomic Layer Epitaxy (ALE) with its self-limiting growth process is a promising method to fulfil the requirements in controlled deposition of high-quality thin films and stacks of thin films with tailored interfaces. In the present paper the investigations on ALE deposition of different oxide (Ti, $\mathrm{Zr}, \mathrm{Hf}, \mathrm{Al}, \mathrm{Ta}, \mathrm{In}, \mathrm{Zn}, \mathrm{Sn})$ and nitride $(\mathrm{Nb}, \mathrm{Ti}, \mathrm{Al}, \mathrm{Ga}, \mathrm{In})$ thin films are reviewed. 


\section{ALE METHOD}

In ALE the reactant vapors are pulsed onto the substrate alternately one at a time and purged with an inert gas between the reactant pulses. With a proper adjustment of the experimental conditions it is possible to get an exact one monolayer of the reactant to chemisorb on the surface. The real growth rate is often lower than one monolayer/cycle because of the steric hindrances of the chemisorbed precursor molecules [15]. For example in the growth of $\mathrm{ZnS}$ by the reaction (Fig. 1)

$\mathrm{ZnCl}_{2}(\mathrm{~g})+\mathrm{H}_{2} \mathrm{~S}(\mathrm{~g})->\mathrm{ZnS}(\mathrm{s})+2 \mathrm{HCl}(\mathrm{g})$

2-3 cycles are needed for a complete monolayer [16], but the reaction

$\mathrm{Ca}(\text { thd })_{2}(\mathrm{~g})+\mathrm{H}_{2} \mathrm{~S}(\mathrm{~g})->\mathrm{CaS}(\mathrm{s})+2 \mathrm{Hthd}(\mathrm{g})$

(thd = 2,2,6,6-tetramethyl-3,5-heptanedione) needs 5-6 cycles for the formation of a CaS monolayer [17]. The special feature of the ALE method is, however, that the growth rate is self-controlled and stable in a certain temperature range, "ALE-window" [18]. Thus the thickness of the film can be controlled by the number of reaction cycles.
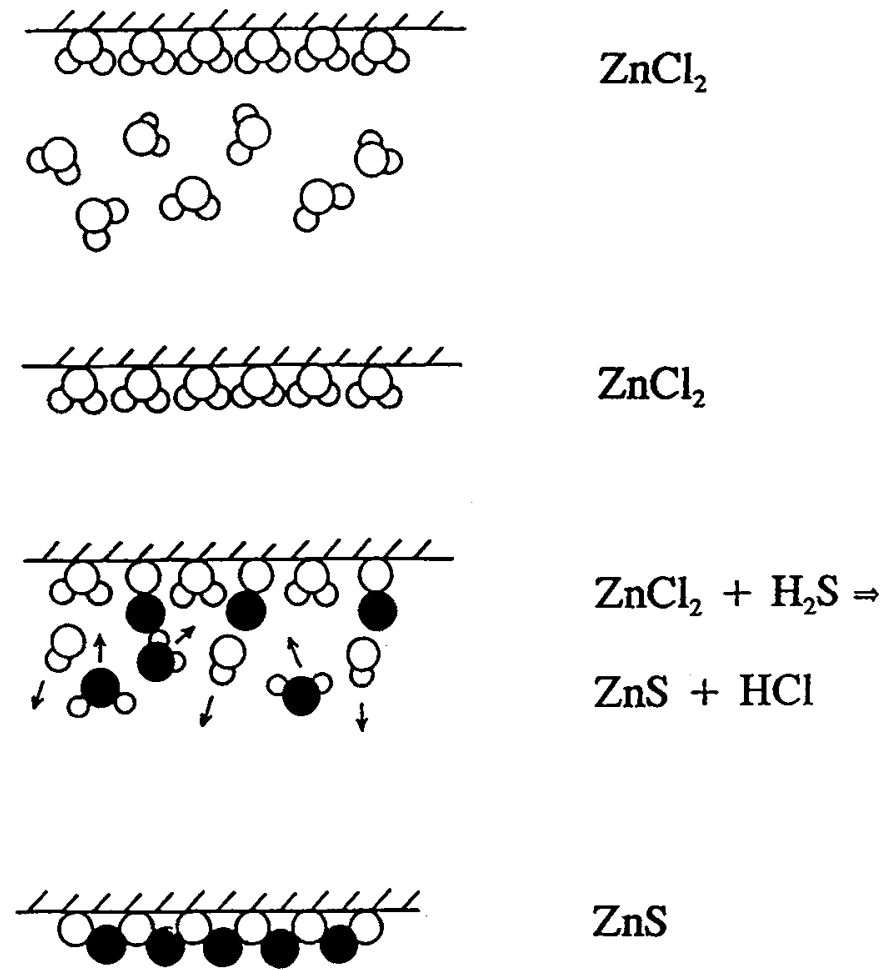

$\mathrm{ZnS}$

Figure 1. The princinle of the ALE-process showing the growth of $\mathrm{ZnS}$ film from $\mathrm{ZnCl}$, and $\mathrm{H}_{3} \mathrm{~S}$. 


\subsection{Characteristic features of ALE}

The characteristic features of ALE and their implications to the process are summarized in Table 1. The obvious advantages are listed as well.

Disadvantages of the ALE method are slow growth rate and low precursor utilization efficiency. These disadvantages can be compensated by reactor and precursor design. The semiclosed travelling wave reactors allow the use of large substrate batches [19]. The precursors preferred in ALE, contradictory to CVD, are those reacting aggressively with each other.

The crystallinity in the thin films depends on the substrate and film material. In ALE single crystalline, "epitaxial" films are obtained if single crystal substrates are employed. In large area applications, like electroluminescent (EL) devices, however, cheap amorphous glass substrates have to be used. The ALE films deposited on glass are amorphous or polycrystalline depending on the film composition. Since the word epitaxy is generally used only in connection to the growth of single crystal films, the use of term ALE in deposition of amorphous films has led to some misunderstandings. Therefore very different names have been adapted to the processes carried out according to the principles of ALE: atomic layer deposition, chemical vapor atomic layer deposition, atomic layer growth, successive layer-wise chemisorption, pulsed beam chemical vapor deposition, sequential surface chemical reaction growth, molecular layer epitaxy and digital layer epitaxy [18,20]. Especially atomic layer deposition is gaining more acceptance [21-24]. In this paper the term ALE is used in its original meaning: growth of thin films in a self-controlled manner using alternate dosing of the reactants. In this meaning ALE covers the deposition of amorphous, polycrystalline and single crystalline thin films.

Table 1. Summary of the characteristic features of ALE, their implications on the film growth and the consequent practical advantages.

\begin{tabular}{|c|c|c|}
\hline $\begin{array}{l}\text { Characteristic feature of } \\
\text { ALE }\end{array}$ & Inherent implication on film deposition & Practical advantage \\
\hline \multirow[t]{3}{*}{$\begin{array}{l}\text { Self-limiting growth } \\
\text { process }\end{array}$} & $\begin{array}{l}\text { Film thickness is dependent only on } \\
\text { the number of deposition cycles }\end{array}$ & Accurate and simple thickness control \\
\hline & No need of reactant flux homogeneity & $\begin{array}{l}\text { Large area capability } \\
\text { Large batch capability } \\
\text { Excellent conformality } \\
\text { No problems with inconstant vaporization } \\
\text { rates of solid precursors } \\
\text { Good reproducibility } \\
\text { Straightforward scale-up }\end{array}$ \\
\hline & $\begin{array}{l}\text { Atomic level control of material } \\
\text { composition }\end{array}$ & $\begin{array}{l}\text { Capability to produce sharp interfaces } \\
\text { and superlattices } \\
\text { Possibility to interface modification }\end{array}$ \\
\hline \multirow[t]{2}{*}{$\begin{array}{l}\text { Separate dosing of } \\
\text { reactants }\end{array}$} & No gas phase reactions & $\begin{array}{l}\text { Favors precursors highly reactive } \\
\text { towards each other, thus enabling } \\
\text { effective material utilization }\end{array}$ \\
\hline & $\begin{array}{l}\text { Sufficient time is provided to complete } \\
\text { each reaction step }\end{array}$ & $\begin{array}{l}\text { High quality materials are obtained at low } \\
\text { processing temperatures }\end{array}$ \\
\hline $\begin{array}{l}\text { Processing temperature } \\
\text { windows are often wide }\end{array}$ & $\begin{array}{l}\text { Processing conditions of different } \\
\text { materials are readily matched }\end{array}$ & $\begin{array}{l}\text { Capability to prepare multilayer structures } \\
\text { in a continuous process }\end{array}$ \\
\hline
\end{tabular}




\subsection{Equipments}

ALE growth has been realized in different reactor types. In the growth of epitaxial III-V or II-VI semiconductors on single crystalline substrates low-pressure MBE reactors have been employed $[25,26]$. Several modifications, including MOVPE type sources for metalorganics and hydrides in a MBE reactor [27], small MOVPE type reactor [28] or moving and rotating substrates for the pulsing of the reactants [29-31], have been developed. The use of laser irradiation may enhance the surface reactions and film growth. For example in the reaction

$$
\mathrm{Ga}\left(\mathrm{CH}_{3}\right)_{3}(\mathrm{~g})+\mathrm{AsH}_{3}(\mathrm{~g})->\mathrm{GaAs}(\mathrm{s})+3 \mathrm{CH}_{4}(\mathrm{~g})
$$

one monolayer per cycle growth has been obtained when laser irradiation was used during the exposure of $\mathrm{Ga}\left(\mathrm{CH}_{3}\right)_{3}$ [32,33]. In the deposition of polycrystalline and amorphous films the flow type reactor is most often used [34,35]. The precursors having vapor pressure high enough at room temperature may be dosed into the reactor from external reservoirs by means of their own pressure while low vapor pressure reactants are vaporized from open boats inside the reactor. The pulsing of the latter is accomplished by inert gas valving [36]. The substrates may locate in the reactor face to face separated by a narrow channel or back to back leaving a more open reactor space. The experiments and results mainly reviewed in this paper have been carried out in a narrow channel reactor made by Microchemistry Ltd, Espoo, Finland [35]. In the narrow channel the precursor molecules undergo numerous collisions with the substrate surfaces which makes the adsorption more probable, fastens the growth and improves the precursor utilization. This all means that short pulse and purge times $(<0.5 \mathrm{~s})$ are possible.

\subsection{ALE activities}

The ALE method was developed by Suntola et al. [37] about twenty years ago when they studied new deposition methods to fabricate thin film electroluminescent (TFEL) displays. These displays need a luminescent layer which is sandwiched between dielectric and conductive layers. This application is demanding since low process temperatures have to be used because of the soda lime glass substrates. In addition large substrate sizes are needed and no pinholes are accepted. Suntola et al. were able to grow polycrystalline luminescent $\mathrm{ZnS}: \mathrm{Mn}$ films and amorphous $\mathrm{Al}_{2} \mathrm{O}_{3}$ films by dosing sequentially the precursors. The quality of the ALE grown TFEL devices is high [38] and the method is industrially used in the production of monochrome and multicolor TFEL devices $[39,40]$.

Worldwidely the studies on ALE are mainly focused on the growth of epitaxial III-V thin films giving emphasis on the self-limiting mechanisms in the growth of GaAs using trimethyl gallium $[41,42]$. The research activity in other areas has been amazingly low despite the fact that the only industrial applications have been in display devices where polycrystalline II-VI compounds and amorphous oxides are utilized. During the last years some increase in the activity in this sector can be recognized.

A new extension of the ALE method is its use in deposition on porous, high-surface-area substrates (silica, alumina) used as catalyst supports [43]. The basic work in this field includes the deposition of different transition metal oxides. 


\section{THERMODYNAMIC CONSIDERATIONS}

In studying the deposition of thin films using new precursor - film material combinations thermodynamic considerations of the reactions prior to experimental work are useful. By calculating $\Delta \mathrm{G}$ it is possible to predict the most feasible reaction. Unlike in CVD, where reactions with negative but close to zero $\Delta G$ are preferred to avoid uncontrolled gas phase reactions, in ALE the reactions should possess as negative $\Delta G$ values as possible, i.e. the precursors should react aggressively with each other. The high reactivity facilitates a use of short cycle times and a material efficient production of films with high purity. However, the final answer whether the film growth is taking place or not cannot be achieved only by the thermodynamic considerations for a few reasons. First the thermodynamic data available is limited to rather simple molecules and inorganic compounds. The HSC program by Outokumpu [44] we utilize contains data for 7708 species. The lack of data for organometallics and volatile metal complexes containing organic ligands is a serious limitation. Secondly, the thermodynamic study of reactions require that the reactants encounter each other in the gas phase but in the ALE method the precursors are not simultaneously present in the gas phase. The precursors chemisorb on the surface and possibly decompose partially, i.e. release one or two ligands. The film formation reaction occurs between these surface species. Thermodynamic data for these surface species are of course not known. Thirdly the thermodynamic considerations tell nothing about the kinetics.

In spite of the limitations it is possible to exclude impossible reactions by the thermodynamic calculations and save time in experimental work. The calculations appeared to be very useful in choosing reactions for the deposition of metal nitride thin films from metal chlorides and ammonia at low temperatures (Fig. 2). In growth of transition metal nitrides ( $\mathrm{TiN}, \mathrm{NbN}$ ) where reduction of the metal is necessary for the nitride formation thermodynamics assists in finding suitable reducer $[45,46]$ which in this case is metallic zinc. Hydrogen does not assist in reducing these metal chlorides

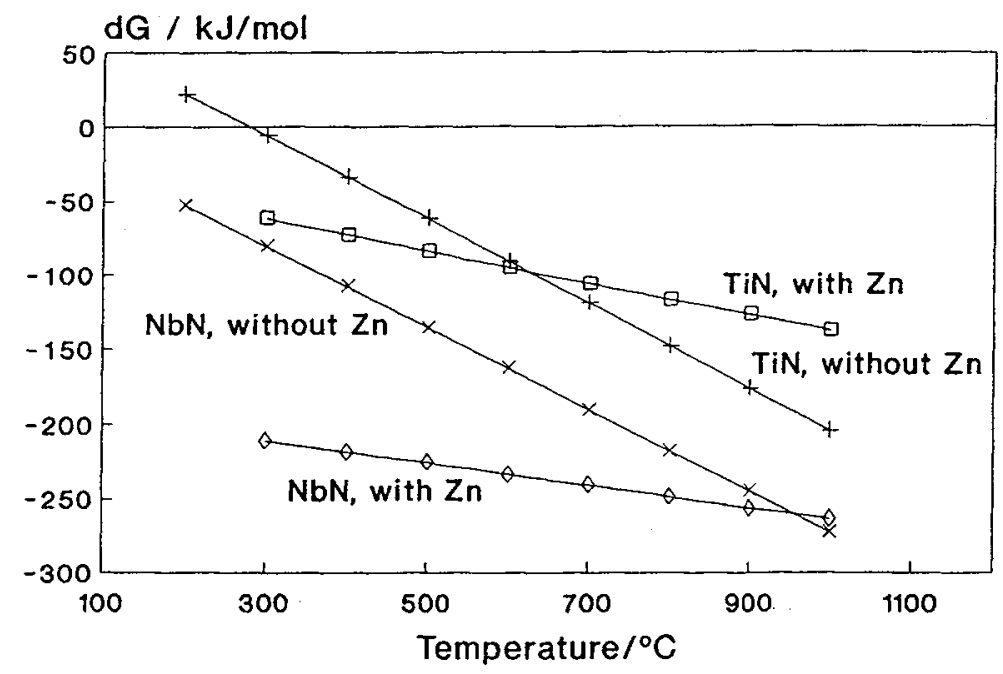

Figure 2: Gibbs energy vs. temperature for the growth reactions of TiN and $\mathrm{NbN}$ with and without $\mathrm{Zn}$ [44].

TiN without $\mathrm{Zn}: \mathrm{TiCl}_{4}(\mathrm{~g})+2 \mathrm{NH}_{3}(\mathrm{~g})=\mathrm{TiN}(\mathrm{s})+4 \mathrm{HCl}(\mathrm{g})+\mathrm{H}_{2}(\mathrm{~g})+0.5 \mathrm{~N}_{2}(\mathrm{~g})$

TiN with $\mathrm{Zn}: \mathrm{TiCl}_{4}(\mathrm{~g})+\mathrm{NH}_{3}(\mathrm{~g})+0.5 \mathrm{Zn}(\mathrm{g})=\mathrm{TiN}(\mathrm{s})+3 \mathrm{HCl}(\mathrm{g})+0.5 \mathrm{ZnCl}_{2}(\mathrm{~g})$

$\mathrm{NbN}$ without $\mathrm{Zn}: \mathrm{NbCl}_{5}(\mathrm{~g})+5 / 3 \mathrm{NH}_{3}(\mathrm{~g})=\mathrm{NbN}(\mathrm{s})+5 \mathrm{HCl}(\mathrm{g})+1 / 3 \mathrm{~N}_{2}(\mathrm{~g})$

$\mathrm{NbN}$ with $\mathrm{Zn}: \mathrm{NbCl}_{5}(\mathrm{~g})+\mathrm{NH}_{3}(\mathrm{~g})+\mathrm{Zn}(\mathrm{g})=\mathrm{NbN}(\mathrm{s})+3 \mathrm{HCl}(\mathrm{g})+\mathrm{ZnCl}_{2}(\mathrm{~g})$ 
from their higher oxidation states to $+\mathrm{III}$; the direct reactions with $\mathrm{NH}_{3}$ are more feasible than those where also hydrogen is involved.

Thermodynamic calculations may also help in understanding and interpreting poor and negative results obtained in deposition experiments. That was the case in our studies on the ALE deposition of $\mathrm{Nb}_{2} \mathrm{O}_{5}$ films from $\mathrm{NbCl}_{5}$ and water where the process was irreproducible and resulted in films with severe thickness non-uniformities [45]. On the basis of thermodynamic calculations the results could be rationalized by the formation of stable $\mathrm{NbOCl}_{3}$ and $\mathrm{NbO}_{2} \mathrm{Cl}$ compounds. Especially the volatile $\mathrm{NbOCl}_{3}$ can lead to etching of $\mathrm{Nb}_{2} \mathrm{O}_{5}$.

\section{OXIDE THIN FILMS}

The deposition of oxides was one of the first experiments made by ALE in 70s [37]. These oxides were aimed for dielectric films in TFEL devices. During the last 15 years several oxide thin films including $\mathrm{MgO}, \mathrm{ZnO}, \mathrm{TiO}_{2}, \mathrm{ZrO}_{2}, \mathrm{HfO}_{2}, \mathrm{SnO}_{2}, \mathrm{CeO}_{2}, \mathrm{Al}_{2} \mathrm{O}_{3}, \mathrm{In}_{2} \mathrm{O}_{3}, \mathrm{Ta}_{2} \mathrm{O}_{5}, \mathrm{Y}_{2} \mathrm{O}_{3}, \mathrm{BaTiO}_{3}$ and $\mathrm{MgAl}_{2} \mathrm{O}_{4}$ have been deposited by ALE as reviewed by Ritala [20].

\subsection{Deposition chemistry}

Metal chlorides and water have most often been used as precursors in ALE deposition of oxide films. The chlorides are often good precursors because they are stable, volatile enough, reactive, cheap and not too difficult to handle [15]. The drawbacks of metal chlorides are that they in some cases $\left(\mathrm{NbCl}_{5}, \mathrm{TaCl}_{5}\right)$ may etch the film leading to a very slow growth rate of the oxide [45,47] or the reaction from chloride to oxide is not thermodynamically favored $\left(\mathrm{ZnCl}_{2}, \mathrm{InCl}_{3}\right)$. Alternative precursors are different organometallic compounds (methyl-, ethyl-, cyclopentadienyl compounds)[48-50], alkoxides [51-53] and $\beta$-diketonates [54,55]. Water is suitable oxygen source if metal chlorides $[36,56-58]$ or alkyl precursors are used $[50,59,60]$ but water is not necessarily the best choice to be used in combination with $\beta$-diketonates. Other possible oxygen sources are $\mathrm{O}_{2}[61]$, $\mathrm{H}_{2} \mathrm{O}_{2}$ [48], alcohols [51], $\mathrm{O}_{3}[54,55]$ and $\mathrm{N}_{2} \mathrm{O}$ [62].

The most intensively studied ALE oxides are $\mathrm{Al}_{2} \mathrm{O}_{3}$ and $\mathrm{TiO}_{2}$. These both oxides have been deposited from different precursors: chlorides, alkoxides and $\mathrm{Al}_{2} \mathrm{O}_{3}$ from aluminium alkyls. The net reactions between metal chlorides and water are simple but the mechanisms of the surface reactions leading to the formation of oxide film may be complex [20,57]. The essential question in the interpretation of the mechanisms is if the surface is hydroxyl terminated or not after the water pulse. If the surface contains hydroxyl groups they are the places with which the metal chloride is reacting. In the case of $\mathrm{TiCl}_{4}$ we can write:

$\mathrm{n}(-\mathrm{OH})(\mathrm{s})+\mathrm{TiCl}_{4}(\mathrm{~g})->(-\mathrm{O}-)_{\mathbf{n}} \mathrm{TiCl}_{4-\mathrm{n}}(\mathrm{s})+\mathrm{nHCl}(\mathrm{g})$

where $\mathbf{n}$ is 1-3 mostly depending on the temperature and spatial distribution of the hydroxyls. The successive water pulse changes the surface back to a hydroxylated one:

$(-\mathrm{O}-)_{\mathrm{n}} \mathrm{TiCl}_{4-\mathrm{n}}(\mathrm{s})+(4-\mathrm{n}) \mathrm{H}_{2} \mathrm{O}(\mathrm{g})->(-\mathrm{O}-)_{\mathrm{n}} \mathrm{Ti}(\mathrm{OH})_{4-\mathrm{n}}(\mathrm{s})+(4-\mathrm{n}) \mathrm{HCl}(\mathrm{g})$

There is a possibility, however, that $\mathrm{TiCl}_{4}$ reacts with the $\mathrm{OH}$-groups in a way that volatile transient species $\mathrm{Ti}(\mathrm{OH})_{4-\mathrm{x}} \mathrm{Cl}_{\mathrm{x}}$ are formed and this complicates the situation since $\mathrm{Ti}(\mathrm{OH})_{4-\mathrm{x}} \mathrm{Cl}_{\mathrm{x}}$ may further react with the surface hydroxyls or decompose to $\mathrm{TiO}_{2}$ or $\mathrm{TiOCl}_{2}[63,64]$. On the other hand, $\mathrm{HCl}$ 
which is released in reactions 4 and 5 has a possibility to readsorb interacting either with the hydroxyl groups or oxygen bridges $[20,65]$. When readsorbed, $\mathrm{HCl}$ blocks the adsorption sites thereby lowering the growth rate. The growth mechanism (reactions 4 and 5) is supported by the mass spectrometric studies which showed both in the case of $\mathrm{Al}$ and $\mathrm{Ti}$ oxide that $\mathrm{HCl}$ is released both after the metal chloride and water pulses [66]. Furthermore, the amount of $\mathrm{HCl}$ after the $\mathrm{TiCl}_{4}$ pulse was lower than expected suggesting that the readsorption of $\mathrm{HCl}$ does play a role. The other possibility is that the surface becomes dehydroxylated after the water pulse. In that case $\mathrm{TiCl}_{4}$ would adsorb molecularly:

$$
(-\mathrm{O}:)(\mathrm{s})+\mathrm{TiCl}_{4}(\mathrm{~g})->(-\mathrm{O}:) \mathrm{TiCl}_{4}(\mathrm{~s})
$$

or dissociatively

$$
(-\mathrm{O}:)(\mathrm{s})+-\mathrm{Ti}(\mathrm{s})+\mathrm{TiCl}_{4}(\mathrm{~g})->(-\mathrm{O}:) \mathrm{TiCl}_{3}(\mathrm{~s})+\mathrm{Ti}-\mathrm{Cl}(\mathrm{s})
$$

The subsequent water pulse converts the surface to oxide and liberates $\mathrm{HCl}$. Also here during the water pulse the formation of volatile transient $\mathrm{Ti}(\mathrm{OH})_{4-\mathrm{x}} \mathrm{Cl}_{\mathrm{x}}$ molecules is possible. Thus the weak $\mathrm{HCl}$ signal after the $\mathrm{TiCl}_{4}$ pulse in mass spectrometry may also indicate that at least partial dehydroxylation takes place at the temperatures (around $500^{\circ} \mathrm{C}$ ) usually used in the ALE growth of oxides from chlorides and water.

The growth rates observed in chloride processes carried out at $500^{\circ} \mathrm{C}$ are $0.6 \AA /$ cycle for $\mathrm{Al}_{2} \mathrm{O}_{3}$ [51,56], around $0.5 \AA /$ cycle for $\mathrm{TiO}_{2}[57], \mathrm{ZrO}_{2}$ [58] and $\mathrm{HfO}_{2}[67], 0.43 \AA /$ cycle for $\mathrm{Ta}_{2} \mathrm{O}_{5}[24], 0.27$ $\AA /$ cycle for $\mathrm{In}_{2} \mathrm{O}_{3}[68]$ and $0.34 \AA /$ cycle for $\mathrm{SnO}_{2}$ [69]. The results show that only a submonolayer is growing during one cycle. The obvious reason for the low growth rate is the steric hindrance caused by the chloro ligands. The other reasons maybe the dehydroxylation which limits the number of reaction sites available, the formation of volatile hydroxide chloride species and the readsorption of $\mathrm{HCl}$. It is worth noticing that the growth rate seems to be higher $(>1 \AA / \mathrm{cycle})$ at lower temperatures $\left(150-200^{\circ} \mathrm{C}\right)[24,51,56]$ because of the larger amount of hydroxyl groups at the surface. At low temperatures, however, the contents of chloride and hydroxide residues in the films may be high weakening the film properties which can be seen in the refractive index values and etching properties.

Also in the reaction between metal alkyls and water the hydroxyl groups evidently play an important role. The lack of chloride ions makes the reaction simpler and high growth rates $(>1$ $\AA /$ cycle) and uniform, thickness profile-free oxide films have been obtained by employing metal alkyl precursors $[50,59,60]$.

The effect of the source chemical on the growth reaction has been studied in the case of $\mathrm{Al}, \mathrm{Ti}$ and Ta oxides using alkoxides as alternative precursors [51-53,70]. Water served also here as an oxygen source. The alkoxides are common precursors in CVD because they can decompose to oxides. In ALE process the competing decomposition process has to be taken into account and this limits the process temperatures below $400^{\circ} \mathrm{C}$. If the growth is taking place in an ALE mode, i.e. if not significant self-decomposition is happening, the growth mechanism is the same as in the case of chlorides. This means that the reaction proceeds via hydroxylated surfaces and alcohols are liberated in the reactions. The size of the precursor molecule was found to affect the growth rate, i.e. the larger the molecule the lower the growth rate: with $\mathrm{Ti}\left(\mathrm{OCH}_{2} \mathrm{CH}_{3}\right)_{4} 0.35 \AA$ cycle [53] and with $\mathrm{Ti}\left(\mathrm{OCH}\left(\mathrm{CH}_{3}\right)_{2}\right)_{4} 0.30 \AA /$ cycle [52]. The exchange reaction with water was faster with the isopropoxide, saturating within $0.6 \mathrm{~s}$ at $250^{\circ} \mathrm{C}$, than with the ethoxide $(1.5 \mathrm{~s})$ indicating the difference in shielding of the metal ions in these alkoxides. 
The crystalline outcome of the oxide films is dependent on several factors like the film material itself, substrate material, film thickness, growth temperature and precursors employed. When deposited on glass some of the ALE oxides $\left(\mathrm{Al}_{2} \mathrm{O}_{3}\right.$ [51,56], $\mathrm{Ta}_{2} \mathrm{O}_{5}$ [70,71]) are completely amorphous to XRD while some others (e.g. $\mathrm{HfO}_{2}$ [67], $\mathrm{In}_{2} \mathrm{O}_{3}$ [68]) possess highly oriented crystalline structures. On the other hand, the substrate material was found to have a significant effect on the crystallinity of the $\mathrm{TiO}_{2}$ films grown from $\mathrm{TiCl}_{4}$ and water [57]. Films having their thicknesses below $200 \mathrm{~nm}$ were essentially amorphous when deposited on amorphous substrates whereas those on crystalline substrates were more crystalline. However, when the film thickness was increased further also those $\mathrm{TiO}_{2}$ films which were grown on glass exhibited increasing tendency towards crystallization [72]. This implies that an amorphous or poorly crystalline layer is first formed on the surface of the amorphous substrate and only subsequently the growth of crystalline material becomes favorable. In fact such a starting layer, though thinner than $40 \mathrm{~nm}$, was found to precede also the deposition of the strongly oriented crystalline $\mathrm{HfO}_{2}$ [67]. Electron diffraction studies, in turn, have revealed that the crystallization of $\mathrm{TiO}_{2}$ and the formation of its different polymorphic phases are mainly dependent on substrate temperature [23]. The effect of the source material on the crystallinity of $\mathrm{TiO}_{2}$ films is illustrated in Fig. 3. By contrast to the essentially amorphous film obtained from $\mathrm{TiCl}_{4}$ at $500{ }^{\circ} \mathrm{C}$ [57], the films deposited from the alkoxides are more crystalline despite the fact they were grown below $350{ }^{\circ} \mathrm{C}[52,53]$. This difference is attributed to the oligomerization of the alkoxides. By bridging between $\mathrm{Ti}$ ions at the surface, the alkoxide groups may form a constructive intermediate between an irregular adsorption layer and a crystalline film.

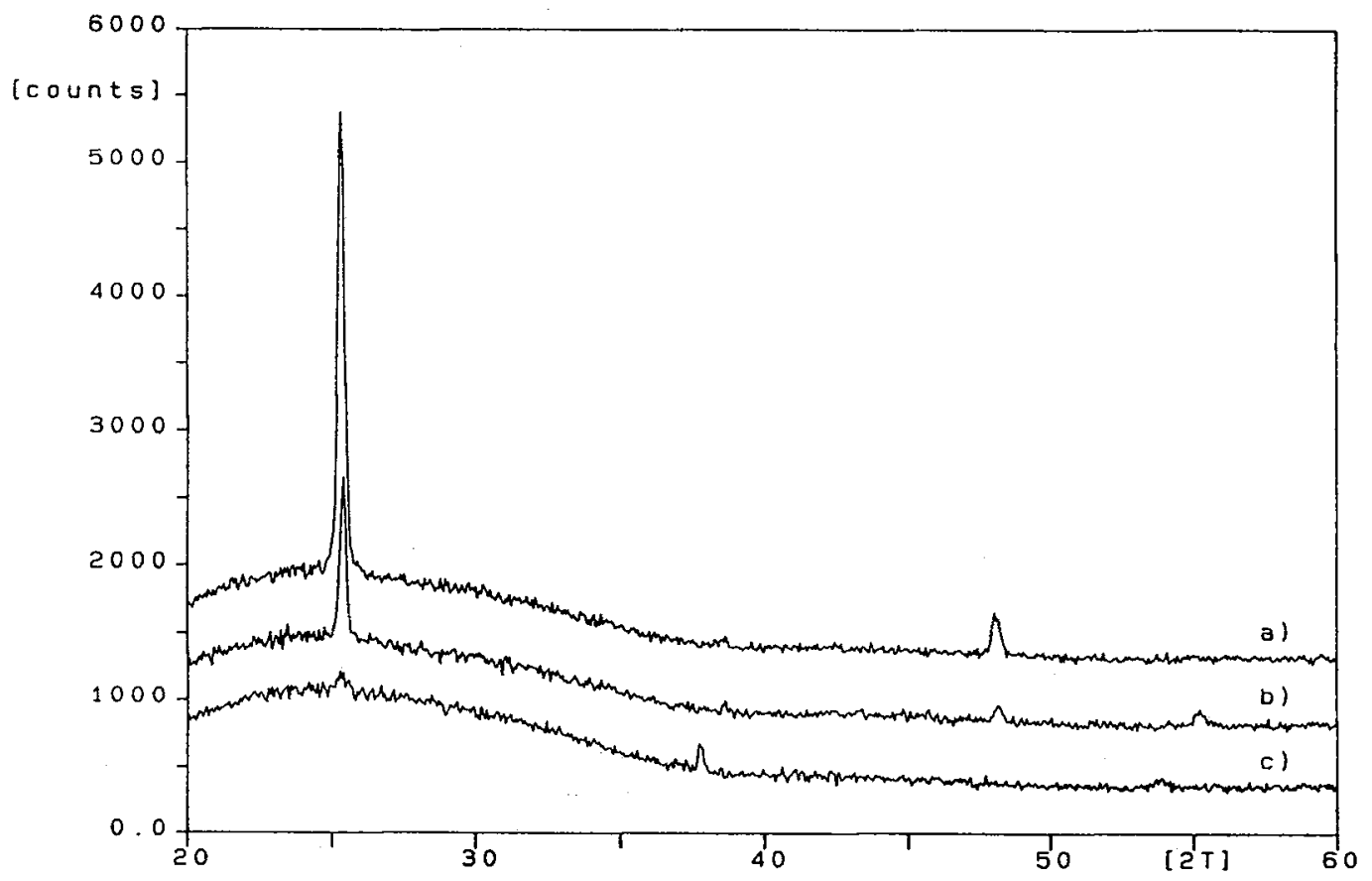

Figure 3: XRD patterns of $120 \mathrm{~nm}$ thick $\mathrm{TiO}_{2}$ films grown on soda lime glass substrates from (a) titanium tetraisopropoxide at $325^{\circ} \mathrm{C}$, (b) titanium tetraethoxide at $250^{\circ} \mathrm{C}$ and (c) $\mathrm{TiCl}_{4}$ at $500^{\circ} \mathrm{C}$. In all the cases the other precursor was water. 


\subsection{Dielectric oxides}

$\mathrm{Al}_{2} \mathrm{O}_{3}$ was the first dielectric oxide deposited by $\mathrm{ALE}$ and it was aimed for dielectric layers in TFEL devices [37]. The main purpose of the insulator is to protect the phosphor layer from a dielectric breakdown. Accordingly, insulators must have high resistivity, dielectric strength and capacitance. Other important properties of the insulator layer are of course good adhesion, chemical stability, small number of pinholes, high charge storage density and small dielectric loss [38,73]. ALE deposited $\mathrm{Al}_{2} \mathrm{O}_{3}$ films fulfil the demands of TFEL devices: dielectric constant $=8.3$, breakdown voltage $>10^{6} \mathrm{~V} / \mathrm{cm}$ and they are pinhole free [71].

The electric properties, viz. losses and toleration of electric field, of $\mathrm{Al}_{2} \mathrm{O}_{3}$ films can be improved by doping it with $\mathrm{TiO}_{2}$. In commercial TFEL displays fabricated by ALE at least one of the dielectric layers is $\mathrm{Al}_{\mathrm{x}} \mathrm{Ti}_{\mathrm{y}} \mathrm{O}_{\mathrm{z}}$ [74].

Tantalum oxide has also been used in the early stage ALE TFEL devices as a dielectric layer [75]. $\mathrm{Ta}_{2} \mathrm{O}_{5}$ has higher dielectric constant (23-25) than $\mathrm{Al}_{2} \mathrm{O}_{3}$ but when the dielectric constant increases the leakage current tends to increase simultaneously [71]. Dielectric losses in ALE grown $\mathrm{Ta}_{2} \mathrm{O}_{5}$ films are in the order of $10^{-2}$ but the leakage current is significant in oxides prepared from chloride and still 2.3-4.0 $\mathrm{mA} / \mathrm{cm}^{2}$ at $1 \mathrm{MV} / \mathrm{cm}$ in those prepared from ethoxide [70,71]. The leakage current can be reduced by several orders of magnitude by introducing thin layers of another oxide to $\mathrm{Ta}_{2} \mathrm{O}_{5}$, i.e. by composite films. So far the systems $\mathrm{Ta}_{2} \mathrm{O}_{5}-\mathrm{Al}_{2} \mathrm{O}_{3}, \mathrm{Ta}_{2} \mathrm{O}_{5}-\mathrm{HfO}_{2}$ and $\mathrm{Ta}_{2} \mathrm{O}_{5}-\mathrm{ZrO}_{2}$ have been studied and they show how the ALE method enables, besides decreasing the leakage current, also tailoring of dielectric constant and refractive index with the aid of multilayer structures $[71,76,77]$.

\subsection{Conducting oxides}

Conducting oxides deposited by ALE include $\mathrm{In}_{2} \mathrm{O}_{3}, \mathrm{In}_{2} \mathrm{O}_{3}: \mathrm{Sn}$ (ITO), $\mathrm{SnO}_{2}, \mathrm{SnO} 2: \mathrm{Sb}, \mathrm{ZnO}$ and $\mathrm{ZnO}: \mathrm{Al}$.

Polycrystalline $\mathrm{In}_{2} \mathrm{O}_{3}$ films with low resistivity and high transparency were deposited from $\mathrm{InCl}_{3}$ and water at $500^{\circ} \mathrm{C}[68]$. This process suffered, however, from low growth rate $(0.27 \AA /$ cycle $)$ which was related to an etching tendency of $\mathrm{InCl}_{3}$ and its decomposition products. The resistivities of the films were in the order of $3 \times 10^{-3} \Omega \mathrm{cm}$. The doping of the $\mathrm{In}_{2} \mathrm{O}_{3}$ films by tin decreased further the growth rate to $0.20 \AA$ /cycle. Two different doping schemes were employed, viz. giving one $\mathrm{SnCl}_{4}$ pulse at a time, $(\mathrm{In}-\mathrm{O})_{49} /(\mathrm{Sn}-\mathrm{O})_{1} /(\mathrm{In}-\mathrm{O})_{49} \ldots$ or giving several successive $\mathrm{SnCl}_{4}$ pulses, $(\mathrm{In}-\mathrm{O})_{98} /(\mathrm{Sn}$ $\mathrm{O})_{2} /(\mathrm{In}-\mathrm{O})_{98} \ldots$ The first pulsing scheme resulted in a higher Sn content of the films. Resistivities in the best ITO films were $2 \times 10^{-4} \Omega \mathrm{cm}$, while the carrier concentration was $6.3 \times 10^{20} \mathrm{~cm}^{-3}$ and Hall mobility $45 \mathrm{~cm}^{2} \mathrm{~V}^{-1} \mathrm{~s}^{-1}[78,79]$. The applicability of ALE ITO thin films to a-Si:H solar cells has been demonstrated [80]. In addition, the use of $\mathrm{ALE}$ grown $\mathrm{ITO}-\mathrm{TiO}_{2}$ film pairs in galvanic cells containing $\mathrm{AlOOH}$ as a solid electrolyte has been studied [81].

Tetragonal rutile-type $\mathrm{SnO}_{2}$ was growing in the reaction between $\mathrm{SnCl}_{4}$ and water at $300-600^{\circ} \mathrm{C}$ [69]. The films were nearly stoichiometric, transparent and highly uniform and the maximum growth rate was $0.34 \AA /$ cycle. The resistivity values $(0.06-0.20 \Omega \mathrm{cm})$ increased with increasing film thickness. The values are somewhat higher than usual in $\mathrm{SnO}_{2}$ but typical to those prepared from chloride. Antimony doping of $\mathrm{SnO}_{2}$ did not disturb the growth rate but lowered the resistivity to $1 \times 10^{-3} \Omega \mathrm{cm}$ when one $\mathrm{SbCl}_{5}$ pulse was given after each $75 \mathrm{SnCl}_{4}$ and water pulses [82]. Simultaneously the electron concentration increased from $1.9 \times 10^{19} \mathrm{~cm}^{-3}$ to $7.2 \times 10^{20} \mathrm{~cm}^{-3}$ and the maximum Hall mobility was $27.5 \mathrm{~cm}^{2} \mathrm{~V}^{-1} \mathrm{~s}^{-1}$. The adverse effect of the Sb doping was the decrease of transparency.

$\mathrm{ZnO}$ and $\mathrm{Al}$ doped $\mathrm{ZnO}$ thin films have successfully been deposited with ALE from the corresponding methyl or ethyl compounds and water [50]. The effect of steric hindrance on the 
growth rate can nicely be seen by comparing the rates obtained with dimethyl zinc $(1.8 \AA /$ cycle at $\left.200^{\circ} \mathrm{C}\right)$ and diethyl zinc $(1.4 \AA / \mathrm{cycle})$. The resistivities were in the order of $8-9 \times 10^{-4} \Omega \mathrm{cm}$ (sheet resistance $10 \Omega / \square$ ) in the films where $3 \%$ of the $\mathrm{Zn}$ pulses were replaced by TMA pulses.

\subsection{Ternary oxides}

The growth of ternary oxides by ALE is a challenge because the achievement of correct stoichiometry is much more difficult than in the binary compounds. Oxide superconductors as quaternary compounds represent even more difficult case and no layer-by-layer ALE growth of, for example, $\mathrm{YBa}_{2} \mathrm{Cu}_{3} \mathrm{O}_{7-\mathrm{x}}$ where the superconducting phase would have been formed in situ has been carried out [10].

Few reports on attempts towards an ALE growth of ternary oxide films exist, however. Huang and Kitai [49] grew polycrystalline $\mathrm{MgO}$ films from bis(cyclopentadienyl)magnesium and water at 400 $900{ }^{\circ} \mathrm{C}$ and amorphous $\mathrm{Al}_{2} \mathrm{O}_{3}$ from triethylaluminium and water. Ternary $\mathrm{MgAl}_{2} \mathrm{O}_{4}$ compound was prepared by pulsing the precursors in a sequence corresponding to the stoichiometry. The resulting films were amorphous and the existence of $\mathrm{Mg}$ and $\mathrm{Al}$ in the films was confirmed by Auger measurements.

$\mathrm{BaTiO}_{3}$ thin films aimed for $\mathrm{EL}$ applications were grown from $\mathrm{Ba} \beta$-diketonate, Ti iso-propoxide and $\mathrm{N}_{2} \mathrm{O}$ on ITO covered glass substrates at $450^{\circ} \mathrm{C}$ [62]. The film obtained was amorphous and contained $\mathrm{Ba}$, Ti and $\mathrm{O}$ as the main components as studied by Auger spectroscopy. The dielectric constant of the film was 19 and the charge storage capacity was $4.2 \mu \mathrm{C} / \mathrm{cm}^{2}$.

\section{NITRIDE THIN FILMS}

In CVD deposition of metal nitrides the most common precursors are metal chlorides with either $\mathrm{N}_{2}$ and $\mathrm{H}_{2}$ or with ammonia [3]. Temperatures below $500{ }^{\circ} \mathrm{C}$ are difficult to achieve with these reactions because of the high chlorine contamination which weakens the film properties [83-87]. Low temperature CVD processes are possible but they require different precursors like metalorganic compounds (alkylamides [88,89], metal alkyl or cyclopentadienyl compounds [86]) and methylhydrazine or tert-butylamine as nitrogen precursors [87] or the use of plasma [90] or hot filament activated [91] processes. In CVD the pyrolysis of complexes containing the metal-nitrogen bond have been used in low-temperature deposition of nitride films [92] but this process may also yield TiCN films [93].

Metal (Al, In, Ti, Nb, Ta, Mo) nitride films can be deposited by ALE from metal chlorides and ammonia at $500{ }^{\circ} \mathrm{C}[45,46,94-96]$. The resulting films are pure and the chlorine content is low - not detectable with RBS and XRF in the case of transition metal nitrides and 3 at-\% in the case of AIN. If the growth temperature in the case of TiN is lowered to $400^{\circ} \mathrm{C}$ the chlorine content increases and the film properties change accordingly. The growth rate in the case of transition metal nitrides is low, around $0.2 \AA /$ cycle but with AlN it is $1 \AA /$ cycle. The reaction $\mathrm{MCl}_{\mathrm{x}}(\mathrm{x}>3)+\mathrm{NH}_{3}$ is not very favorable at these temperatures and additional reduction to $\mathrm{M}^{\mathrm{III}}$ is needed.

To obtain uniform transition metal nitrides with low resistivity a reducing $\mathrm{Zn}$ intermediate pulse can be used between the metal chloride and $\mathrm{NH}_{3}$ pulses $[45,46,97]$. The metallic zinc reduces the surface metal species and forms gaseous $\mathrm{ZnCl}_{2}$ which is purged out. No zinc is remaining in the film. The use of zinc affects the visual appearance of the films, improves their conductivity but does not increase the growth rate. The lowest resistivity measured for TiN films grown with $\mathrm{Zn}$ at 500 ${ }^{\circ} \mathrm{C}$ was $50 \mu \Omega \mathrm{cm}[46]$. 
The nitride films (AlN, TiN) may contain some oxygen and there can be an oxygen profile in the flow direction so that the maximum amount is observed at the leading edge of the substrate. AlN seems to oxidize very easily and the origin of the oxygen may be the nitrogen carrier gas and/or ammonia [95]. The origin of oxygen in TiN was attributed to post depositional oxidation because the oxygen content was lowest in the thickest films. Oxygen is probably located at the surfaces of the grains thus explaining why its relative amount decreases in thicker films where the surface to bulk ratio is smaller. The intermediate $\mathrm{Zn}$ pulse reduced slightly the oxygen content [46].

$\mathrm{NbCl}_{5}$ is still a special case because of its strong etching tendency which further lowers the growth rate. By keeping the pulse time of $\mathrm{NbCl}_{5}$ as short as $0.1 \mathrm{~s}$ and lengthening the $\mathrm{NH}_{3}$ pulse to $1.0 \mathrm{~s}$ a rate of $0.25 \AA$ /cycle could be obtained [45].

Metal alkyl compounds are alternative precursors also in the ALE deposition of nitrides as shown by Mayer et al. [98] who used trimethyl aluminium and ammonia and Asif Khan et al. [99-102] who used triethyl aluminium, triethyl gallium and ammonia in deposition of $\mathrm{GaN}$ and AIN thin films and their superlattices. Smooth, epitaxial nitride film could be deposited on a single crystal substrate already at $450^{\circ}$ which is $250^{\circ} \mathrm{C}$ lower than that used in a conventional low-pressure CVD. Plasmaenhanced ALE has been employed in depositing both single crystal and polycrystalline GaN films from trimethyl gallium and $\mathrm{N}+\mathrm{H}$ plasma on sapphire with different orientations [103]. The substrate surface treatment strongly affected the quality of the film grown.

\section{FILM MORPHOLOGY}

The oxide and nitride films deposited by ALE have been uniform, dense and free of any significant contamination. Their characterization by scanning electron microscopy (SEM) and atomic force microscopy (AFM) have revealed interesting results from the evolution of the surface morphology during the film growth. It was found that the materials grown on glass can be divided in two groups: amorphous with smooth surfaces and polycrystalline with roughened surfaces. Typical totally amorphous materials are $\mathrm{Al}$ and $\mathrm{Ta}$ oxides. The reason to this may be in the surface mobility or in the growth reaction. Both the SEM and AFM measurements show that these oxide films are extremely flat and homogeneous [70,104]. The surface roughness of a $800 \mathrm{~nm}$ thick $\mathrm{Al}_{2} \mathrm{O}_{3}$ films is only about $2 \mathrm{~nm}$.

In polycrystalline films the surface roughness increases with the film thickness which is in an obvious contradiction with the ideal layer-by-layer growth mechanism. The agglomeration starts immediately at the beginning of the film growth [105]. Because the gas-phase reactions can be neglected, the obvious reasons for the agglomeration are the surface migration processes driven by the free-energy associated with the film-substrate interface. In metal chloride - water processes the migration of hydroxyl groups and hydroxide chloride intermediate species may be responsible for the agglomeration and surface roughening. Support to this statement is obtained from the experiments made with $\mathrm{TiCl}_{4}$ and water to deposit $\mathrm{TiO}_{2}$ on amorphous silica powder. In that case strong agglomeration and crystalline $\mathrm{TiO}_{2}$ was detected by XRD even after one reaction cycle and without the water pulse $[64,106,107]$. The apparent consequence of the surface roughening is that when the film becomes thicker and rougher light scattering from its surface becomes significant leading to a milky appearance and reduced specular transparency. In $\mathrm{TiO}_{2}$ films grown by ALE at $500^{\circ} \mathrm{C}$, for example, the light scattering is already significant for films with thicknesses of the order of $400 \mathrm{~nm}$. Besides film thickness also other factors like precursors used, growth temperature and substrate material may affect the surface roughening.

Roughening of $\mathrm{TiO}_{2}$ films could be reduced by intermediate $\mathrm{Al}_{2} \mathrm{O}_{3}$ layers [72]. The $\mathrm{Al}_{2} \mathrm{O}_{3}$ layers prevented the growth of the $\mathrm{TiO}_{2}$ agglomerates and the $\mathrm{TiO}_{2}$ layers had to rebegin the nucleation 
after each aluminium oxide layer. Films which consisted of 20 pairs of $\mathrm{TiO}_{2}-\mathrm{Al}_{2} \mathrm{O}_{3}$ layers where each pair further consisted of $900 \mathrm{Ti}-\mathrm{O}$ and $100 \mathrm{Al}-\mathrm{O}$ cycles, were $850 \mathrm{~nm}$ thick, highly transparent and had surface roughness of $8.2 \mathrm{~nm}$ to be compared with a roughness of $25 \mathrm{~nm}$ measured for a pure $\mathrm{TiO}_{2}$ film with a comparable thickness. The cross-sectional SEM micrographs proved also that the particles in the films containing the intermediate $\mathrm{Al}_{2} \mathrm{O}_{3}$ layers are significantly smaller than those found in pure $\mathrm{TiO}_{2}$ films.

\section{CONCLUSIONS}

ALE is a competitive and versatile method to grow oxide and nitride thin films on large area substrates. The reviewed papers show that uniform dielectric and conductive oxide as well as nitride thin films have been deposited by ALE. The applicability of ALE to an industrial scale is evidenced by its use in fabrication of TFEL displays.

The principle of the ALE method is simple: alternate reactions via saturated surfaces. However, the deeper study of the reaction mechanisms shows the complexity of the process. The full understanding of the growth of e.g. oxide films is not possible by analyzing only the resulting films and growth rates. AFM/STM methods have revealed new information on the growth mechanisms but still in situ monitoring of the reactions is greatly needed to gain a detailed insight into the growth reactions and, thereby, to improve the process control and to assist in designing new ALE processes.

\section{References}

[1] Venkatesan, T., Thin Solid Films 216 (1992) 52-58.

[2] Sneh, O., Wise, M.L., Okada, L.A., Ott, A.W. and George, S.M., Mat. Res. Soc. Symp. Proc. 334 (1994) 25-30.

[3] Pierson, H.O., Handbook of Chemical Vapor Deposition (CVD) (Noyes Publications, Park Ridge, N.J. 1992) pp. 226-242.

[4] Sze, S.M., Semiconductor Devices, Physics and Technology (John Wiley \& Sons, New York, 1985).

[5] Singer, P., Semicond. Int. Sept. (1992) 32.

[6] Bange, K. and Gambke, T., Adv. Mater. 2 (1990) 10-16.

[7] Bauer, G. H., Appl. Surf. Sci. 70/71 (1993) 650-659.

[8] Chopra, K.L., Major, S. and Pandya, K.D., Thin Solid Films 102 (1983) 1-46.

[9] Leskelä, M.A., Truman, K.J., Mueller, C.H. and Holloway, P.H., J. Vac. Sci. Technol. A 7 (1989) 3147-3171.

[10] Leskelä, M., Mölsä, H. and Nïnistö, L., Supercond. Sci. Technol. 6 (1993) 627-656.

[11] Strite, S. and Morkoc, H., J. Vac. Sci. Technol. B 10 (1992) 1237-1266.

[12] Shintani, A. and Minagawa, S., J. Electrochem. Soc. 123 (1976) 1725-1729.

[13] Chatterjee, S., Chandrashekhar, S. and Sudarshan, T.S., J. Mater. Sci. 27 (1992) 3409-3423.

[14] Travis, E.O. and Fiordilace, R.W., Thin Solid Films 236 (1993) 325-329.

[15] Leskelä, M. and Niinistö, L., in Atomic Layer Epitaxy. Suntola, T. and Simpson, M. (Eds.) (Blackie and Son Ltd, Glasgow 1990) pp. 1-39.

[16] Pakkanen, T.A., Nevalainen, V., Lindblad, M. and Makkonen, P., Surf. Sci. 188 (1987) 456-474.

[17] Rautanen, J., Leskelä, M., Niinistö, L., Nykänen, E., Soininen, P. and Utriainen, M., Appl. Surf. 
Sci. 82/83 (1994) 553-558.

[18] Leskelä, M., Acta Polytechn. Scand., Ser. Chem. Technol. 195 (1990) 67-80.

[19] Suntola, T., Thin Solid Films 225 (1993) 96-98.

[20] Ritala, M., Ann. Acad. Sci. Fenn. Ser. A II. Chemica 257 (1994) 1-48.

[21] Huang, R. and Kitai, A.H., J. Mater. Sci. Lett. 12 (1993) 1444-1446.

[22] Ranta-aho, T. and Ylilammi, M., J. Electrochem. Soc. 141 (1994) 1278-1284.

[23] Aarik, J., Aidla, A., Uustare, T. and Sammelselg, V., J. Cryst. Growth 148 (1995) 268-275.

[24] Kukli, K., Aarik, J., Aidla, A., Kohan, O., Uustare, T. and Sammelselg, V., Thin Solid Films. In press.

[25] Goodman, C.H.L. and Pessa, M., J. Appl. Phys. 60 (1986) R65-R81.

[26] Yao, T. and Takeda, T., Appl. Phys. Lett. 48 (1986) 160-162.

[27] Nishizawa, J., Abe, H. and Kurabayashi, T., J. Electrochem. Soc. 132 (1985) 1197-1200.

[28] DenBaars, S.P., Beyler, C.A., Hariz, A., and Dapkus, P.D., Appl. Phys. Lett. 51 (1987) 15301532.

[29] Usui, A. and Sunakawa, H., Jpn. J. Appl. Phys. 25 (1986) L212-L214.

[30] Bedair, S.M., Tischler, M.A., Katsuyama, T. and El-Masry, N.A., Appl. Phys. Lett. 47 (1985) 51-53.

[31] Tischler, M.A. and Bedair, S.M., in Atomic Layer Epitaxy. Suntola, T. and Simpson, M. (Eds.), (Blackie and Son Ltd, Glasgow 1990) pp. 110-154.

[32] Doi, A., Aoyagi, Y. and Namba, S., Appl. Phys. Lett. 48 (1986) 1787-1789.

[33] Karam, N.H., Liu, H., Yoshida, I. and Bedair, S.M., Appl. Phys. Lett. 52 (1988) 1144-1146.

[34] Suntola, T. and Hyvärinen, J., Annu. Rev. Mater. Sci. 15 (1985) 177-195.

[35] Suntola, T., Thin Solid Films 216 (1992) 84-89.

[36] Suntola, T., Pakkala, A. and Lindfors, S., U.S. Patent 4,389,973 (1983).

[37] Suntola, T., Antson, J., Pakkala, A. and Lindfors, S., SID 80 Digest 11 (1980) 108-109.

[38] Sutela, T., Display Technol. Appl. 5 (1984) 73-78.

[39] Karila, J., Hyvärinen, J. and Törnquist, R., Conf. Proc. Eurodisplay 87, Paris 1987, p. 236.

[40] Haaranen, J., Törnqvist, R., Koponen, J., Pitkänen, T., Surma-aho, M., Barrow, W. and Laakso, C., SID 92 Digest 23 (1992) 348-351.

[41] Proceedings of the 1st International Symposium on Atomic Layer Epitaxy, Acta Polytechn. Scand., Ser. Chem. Technol. 195 (1990) Niinistö, L. (Ed.); Proceedings of the 2nd International Symposium on Atomic Layer Epitaxy, Thin Solid Films 225 (1993) Bedair, S.M. (Ed.); Proceedings of the 3rd International Symposium on Atomic Layer Epitaxy, Appl. Surf. Sci. 82/83 (1994) Ozeki, M., Usui, A., Aoyagi, Y. and Nishizawa, J. (Eds.).

[42] Niinistö, L. and Leskelä, M., Thin Solid Films 225 (1993) 130-135.

[43] Lakomaa, E.-L., Appl. Surf. Sci. 75 (1994) 185-196.

[44] Outokumpu HSC Chemistry for Windows program package, Version 1.10 (Outokumpu Research Oy, Pori, Finland, 1993).

[45] Elers, K.-E., Ritala, M., Leskelä, M. and Rauhala, E., Appl. Surf. Sci. 82/83 (1994) 122-125.

[46] Ritala, M., Leskelä, M., Rauhala, E. and Haussalo, P., J. Electrochem. Soc. Submitted.

[47] Aarik, J., Aidla, A., Kukli, K. and Uustare, T., J. Cryst. Growth 144 (1994) 116-119.

[48] Fan, J.K., Sugioka, K. and Toyoda, K., Mat. Res. Symp. Ser. Proc. 222 (1991) 327-332.

[49] Huang, R. and Kitai, A.H., J. Electron. Mater. 22 (1993) 215-220.

[50] Lujala, V., Skarp, J., Tammenmaa, M. and Suntola, T., Appl. Surf. Sci. 82/83 (1994) 34-40.

[51] Hiltunen, L., Kattelus, H., Leskelä, M., Mäkelä, M., Niinistö, L., Nykänen, E., Soininen, P. and Tiitta, M., Mater. Chem. Phys. 28 (1991) 379-388.

[52] Ritala, M., Leskelä, M., Niinistö, L. and Haussalo, P., Chem. Mater. 5 (1993) 1174-1181. 
[53] Ritala, M., Leskelä, M. and Rauhala, E., Chem. Mater. 6 (1994) 556-561.

[54] Mölsä, H., Niinistö, L. and Utriainen, M., Adv. Mater. Optics Electronics 4 (1994) 389-400.

[55] Mölsä, H. and Niinistö, L., Mat. Res. Soc. Symp. Proc. 335 (1994) 341-350.

[56] Aarik, J., Aidla, A., Jaek, A., Kiisler, A.-A. and Tammik, A.-A., Acta Polytechn. Scand., Ser. Chem. Technol. 195 (1990) 201-208.

[57] Ritala, M., Leskelä, M., Nykänen, E., Soininen, P., and Niinistö, L., Thin Solid Films 225 (1993) 288-295.

[58] Ritala, M. and Leskelä, M., Appl. Surf. Sci. 75 (1994) 333-340.

[59] Higashi, G.S. and Fleming, C.G., Appl. Phys. Lett. 55 (1989) 1963-1965.

[60] George, S.M., Sneh, O., Dillon, A.C., Wise, M.L., Ott, A.W., Okada, L.A. and Way, J.D., Appl. Surf. Sci. 82/83 (1994) 460-467.

[61] Oya, G. and Sawada, Y., J. Cryst. Growth 99 (1990) 572-576.

[62] Lee, D.H., Cho, Y.S., Lee, J.K. and Jung, H.J., Mat. Res. Soc. Symp. Proc. 310 (1993) 397-402.

[63] Hair, M.L. and Hertl, W., J. Phys. Chem. 77 (1973) 2070-2075.

[64] Haukka, S., Lakomaa, E.-L. and Root, A., J. Phys. Chem. 97 (1993) 5085-5094.

[65] Parfitt, G.D., Ramsbotham, J. and Rochester, C.H., Trans. Faraday Soc. 67 (1971) 3100-3109.

[66] Sonninen, M. and Hyvärinen, J., Unpublished results.

[67] Ritala, M., Leskelä, M., Niinistö, L., Prohaska, T., Friedbacher, G. and Grasserbauer, M., Thin Solid Films 250 (1994) 72-80.

[68] Asikainen, T., Ritala, M. and Leskelä, M., J. Electrochem. Soc. 141 (1994) 3210-3213.

[69] Viirola, H. and Niinistö, L., Thin Solid Films 249 (1994) 144-149.

[70] Kukli, K., Ritala, M. and Leskelä, M., J. Electrochem. Soc. 142 (1995) 1670-1675.

[71] Kattelus, H., Ylilammi, M., Saarilahti, J., Antson, J. and Lindfors, S., Thin Solid Films 225 (1993) 296-298.

[72] Ritala, M., Leskelä, M., Niinistö, L., Prohaska, T., Friedbacher, G. and Grasserbauer, M., Thin Solid Films 249 (1994) 155-162.

[73] Leskelä, M. and Tammenmaa, M., Mater. Chem. Phys. 16 (1987) 349-371.

[74] Antson, H., Grasserbauer, M., Hamilo, M., Hiltunen, L., Koskinen, T., Leskelä, M., Niinistö, L., Stingeder, G. and Tammenmaa, M., Fresenius Z. Anal. Chem. 322 (1985) 175-180.

[75] Törnqvist, R. and Tuomi, T., J. Lumin. 24/25 (1981) 901-904.

[76] Kattelus, H., Ylilammi, M., Salmi, J., Ranta-aho, T., Nykänen, E. and Suni, I., Mat. Res. Soc. Symp. Proc. 284 (1993) 511-516.

[77] Kukli, K., Ihanus, J., Ritala, M. and Leskelä, M., To be published.

[78] Asikainen, T., Ritala, M. and Leskelä, M., Vacuum. In press.

[79] Asikainen, T., Ritala, M. and Leskelä, M., J. Electrochem. Soc. Submitted.

[80] Ouwens, J.D., Schropp, R.E.I., Wallinga, J., van der Weg, W.F., Ritala, M., Leskelä, M. and Hyvärinen, J., Proc. 12th Europ. Photov. Solar Energy Conf. 1994 pp. 1296-1299.

[81] Turković, A., Musić, S., Dragčević, D., Popović, S., Ritala, M., Asikainen, T. and Leskelä, M., Proceedings of the 8th CIMTEC Conference on Modern Materials \& Technologies, Firenze 1994. In press.

[82] Viirola, H. and Niinistö, L., Thin Solid Films 251 (1994) 127-135.

[83] Hegde, R.I., Fiordalice, R.W., Travis, E.O. and Tobin, P.J., J. Vac. Sci. Technol. B 11 (1993) 1287-1296.

[84] Nickel, K., Riedel, R. and Petzow, G., J. Amer. Ceram. Soc. 72 (1989) 1804-1810.

[85] Pierson, H.O., J. Comp. Mater. 9 (1975) 228-240.

[86] Sherman, A., Jpn. J. Appl. Phys. 30 (1991) 3553-3557.

[87] Price, J.B., Borland, J.O. and Selbrede, S., Thin Solid Films 236 (1993) 311-318. 
[88] Fix, R., Gordon, R.G. and Hoffman, D.M., Chem. Mater. 3 (1991) 1138-1148.

[89] Dubois, L.H., Polyhedron 13 (1994) 1329-1336.

[90] Akahori, T., Tanihara, A. and Tano, M., Jpn. J. Appl. Phys. 30 (1991) 3558-3561.

[91] Deshpande, S.V. and Gulari, E., Mat. Res. Soc. Symp. Proc. 327 (1994) 115-120.

[92] Ho, K., Annapragada, A. and Jensen, K., Proc. 11th Int. Conf. on CVD. Spear, K. and Cullen, G. (Eds.) (Electrochemical Society, Pennington NJ 1990) pp. 388-394.

[93] Eizenberg, M., Littau, K., Ghanayem, S., Mak, A., Maeda, Y., Chang, M. and Sinha, S.K., Appl. Phys. Lett. 65 (1994) 2416-2418.

[94] Higuchi, K., Unno, A. and Shiraishi, T., Mat. Res. Soc. Symp. Proc. 222 (1991) 169-173.

[95] Elers, K.-E., Ritala, M., Johansson, L-S. and Leskelä, M., J. Phys. IV This issue.

[96] Hiltunen, L., Leskelä, M., Mäkelä, M., Niinistö, L., Nykänen, E. and Soininen, P., Thin Solid Films 166 (1988) 149-154.

[97] Nykänen, E., Mäkelä, M., Soininen, P., Leskelä, M. and Niinistö, L., to be published.

[98] Mayer, T.M., Rogers Jr., J.W. and Michalske, T.A., Chem. Mater. 3 (1991) 641-646.

[99] Asif Khan, M., Skogman, R.A., Van Hove, J.M., Olson, D.T. and Kuznia, J.N., Appl.Phys. Lett. 60 (1992) 1366-1368.

[100] Asif Khan, M., Kuznia, J.N., Olson, D.T., Van Hove, J.M., Blasingame, M. and Reitz, L.F., Appl. Phys. Lett. 60 (1992) 2917-2919.

[101] Asif Khan, M., Kuznia, J.N., Skogman, R.A., Olson, D.T., MacMillan, M. and Choyke, W.J., Appl. Phys. Lett. 61 (1992) 2539-2541.

[102] Asif Khan, M., Kuznia, J.N., Olson, D.T., George, T. and Pike, W.T., Appl. Phys. Lett. 63 (1993) 3470-3472.

[103] Hwang, C.-Y., Lu, P., Mayo, W.E., Lu, Y. and Liu, H., Mat. Res. Soc. Symp. Proc. 326 (1994) 347-352.

[104] Ritala, M., Saloniemi, H., Leskelä, M., Prohaska, T., Friedbacher, G. and Grasserbauer, M., Thin Solid Films. Submitted.

[105] Ritala, M., Leskelä, M., Johansson, L.-S. and Niinistö, L., Thin Solid Films 228 (1993) 32-35.

[106] Haukka, S., Lakomaa, E.-L., Jylhä, O., Vilhunen, J. and Hornytzkyj, S., Langmuir 9 (1993) 3497-3506.

[107] Lakomaa, E.-L., Haukka, S. and Suntola, T., Appl. Surf. Sci. 60/61 (1992) 742-748. 
